UNITED IRISHMEN, UNITED STATES 
This page intentionally left blank 


\title{
UNITED IRISHMEN, UNITED STATES
}

Immigrant Radicals in the Early Republic

\author{
DAVID A. WILSON
}

Cornell University Press

Ithaca and London 
Copyright (c) 1998 by Cornell University

All rights reserved. Except for brief quotations in a review, this book, or parts thereof, must not be reproduced in any form without permission in writing from the publisher. For information, address Cornell University Press, Sage House, 512 East State Street, Ithaca, New York 14850.

First published 1998 by Cornell University Press

First printing, Cornell Paperbacks, 2011

Printed in the United States of America

Cornell University Press strives to use environmentally responsible suppliers and materials to the fullest extent possible in the publishing of its books. Such materials include vegetable-based, low-VOC inks and acid-free papers that are also recycled, totally chlorine-free, or party composed of nonwood fibers.

Library of Congress Cataloging-in-Publication Data

Wilson, David A., 1950-

United Irishmen, United States : immigrant radicals in the early republic / David

A. Wilson.

p. $\mathrm{cm}$.

Includes bibliographical references (p. ) and index.

ISBN 0-8014-3175-1 (cloth : alk. paper)

1. Irish Americans-Politics and government. 2. United States-Politics and government-1783-1809. 3. Radicalism-United States-History-18th century. 4. Ireland-Politics and government-1760-1820. 5. United Irishmen. I. Title. E184.I6W47 $1998 \quad 98-10377$

973'.049162-dc21

$\begin{array}{lllllllllll}\text { Cloth printing } & 10 & 9 & 8 & 7 & 6 & 5 & 4 & 3 & 2 & 1\end{array}$ 
No hero hang'd, no hamlet burn'd

No peasant robb'd and a that

No spitefu spy, no coward turned

We never dream't o a that.

The neighbours soon combin'd we saw

In union, love and a that

But love was treason by the law

And so we $\mathrm{p}[\mathrm{a}]$ ied for a that.

And a that, and a that

And twice as mickle's a that

The blessings o America

Will make amends for a that.

-Andrew Parks, "Emigration to America," 1798.

"[I do] not wish to invite hordes of wild Irishmen, nor the turbulent and disorderly of all parts of the world, to come here with a view to disturb our tranquillity."

-Harrison Gray Otis, Debates and Proceedings of Congress, 1797. 
For Liam Kennedy,

and for the memory of Gwyn A. Williams

Ni welir ei debyg byth eto 